\title{
COVENANT OF MAYORS COMMITTED TO LOCAL SUSTAINABLE ENERGY: THE ITALIAN CASE
}

\author{
LUCA ADAMI, GIACOMO CASTAGNA, MARCO RAGAZZI \& MARCO TUBINO \\ Department of Civil, Environmental and Mechanical Engineering, University of Trento, Italy
}

\begin{abstract}
The Paris agreement fixed worldwide targets on the temperature increase below $2{ }^{\circ} \mathrm{C}$ in the XXI century. Presently 176 countries ratified this framework. With the 20-20-20 package, the European Commission fixes three targets: (i) reduction of the European greenhouse gas emissions at least $20 \%$ below 1990 levels by 2020 , (ii) $20 \%$ of EU energy consumption must come from renewable resources by 2020 and (iii) $20 \%$ reduction in primary energy use compared with projected levels, by improving energy efficiency. To achieve these global targets, Covenant of Mayor was launched in 2008 as a voluntary initiative for local administrations that decide to adopt a plan of interventions concerning greenhouse gas mitigations achieving and exceeding the EU climate and energy targets. In the present paper, we analyse the global results of the initiative during its first decade of activity, focusing on the Italian case at national level, since it is presently the leading country in terms of population involved.

Keywords: Covenant of Mayors, climate change, energy efficiency, local energy plans.
\end{abstract}

\section{INTRODUCTION}

Global studies on climate change show that the increased celerity of variations registered in the XX century [1], [2] can sensibly affect natural ecosystems [3], [4] as well as human evolution [5], with potentially drastic scenarios in the long term [6], [7]. This suggests that strategies for sustainable management of such ecosystems should focus on maintaining their resilience [8].

On this direction, the Paris agreement on climate can be considered the leading global framework on the topic, with the following aims [9]-[11]:

- to keep the global temperature rise in XXI century below $2{ }^{\circ} \mathrm{C}$ above pre-industrial levels, possibly limiting this increasing trend to $1.5^{\circ} \mathrm{C}$

- $\quad$ to strengthen the ability of countries to deal with the impacts of climate change.

The European Strategy for Climate change fixes three targets to make Europe more climate-resilient [12]-[15]:

(i) promoting action by Member States

(ii) promoting 'Climate-proofing' actions at European Union (EU) level

(iii) better informing decision-makers

Its low-carbon economy roadmap suggests that by 2050, EU should cut greenhouse gas emissions to $80 \%$ below 1990 levels and intermediate milestones to achieve this goal are $40 \%$ emissions cuts by 2030 and $60 \%$ by 2040 [16]. The first deadline is set in 2020 , in which the goal is to reduce greenhouse gas (GHG) emission by $20 \%$ [17]. To reach this goal EU encourages several actions including all territorial levels, with local emphasis [18]-[21].

Under this perspective, the EU Covenant of Mayors (CoM) for Climate and Energy started in 2008 with the aim to gather local governments to achieving the EU climate and energy targets. Municipalities or groups of them (called "signatories") can adhere to CoM voluntarily and sign a declaration stating that they plan to obtain specific targets of $\mathrm{CO}_{2}$ 
emissions reduction through specific local actions that are described in the Sustainable Energy Action Plan (SEAP) [22]. CoM initiative is part of the world climate change networks such as the Conference of Parties 21, "C40 cities", the ICLEI - Local Governments for Sustainability [23] and the Smart Cities Initiative [24].

Several studies on the topic of the CoM initiative have been published so far, analysing in detail different scales of the initiative, from national [22], [25], to regional [26]-[31] and local [32]-[35]. The comparison between municipalities of different countries has also been considered [36]-[39].

Local authorities play a leading role in the application of the SEAPs [40]-[42] and their economic investments to the global targets of the Paris agreement [43] are supported by citizens [44], [45] even if issues and barriers are still remaining [46]. Opportunities to link these actions to a circular economy vision come from projects like BIOREGIO [47].

Support to GHG reduction at municipal level has recently been afforded by recent studies [48], [49] through tools [50]-[53], indicators [54] and specific actions on several public sectors [55]-[59] that helps administrations improving the effectiveness of the action plans. Despite the broad interest in the initiative and the increasing dimension of the population involved in this initiative $(250+$ million inhabitants and $7700+$ signatories $)$, the status of implementation of the Covenant of Mayors by country is still lacking and an overview of the whole initiative is missing. The focus of the work is to provide a review of the first 10 years of the initiative and the status of implementation of the CoM in Italy, that is actually the country with the largest population involved by this initiative.

\section{THE COVENANT OF MAYORS IN THE DECADE 2008-2017}

Since 2008, CoM initiative provided an increasing number of signatories, both local and regional authorities, reaching in the period 2009-2013 the average of 963 new signatories per year (see Fig. 1(a)). Until 2015, majority of the new signatories fixes the targets of the SEAP to the year 2020. Starting from year 2016, the target of $\mathrm{CO}_{2}$ reduction was updated with the concept of climate mitigation and adaptation with a 2030 horizon. Action plan in this case is called Sustainable Energy and Climate Action Plan (SECAP).

From 2014, signatories started publishing the so-called Progress Plans (see Fig. 1(b)). Two types can be published: (i) the Monitoring Report, related to the mitigation and adaptation actions adopted, every two years; (ii) the Emission Inventory, related to resilience to climate change, reduction of emission and energy consumption, every four years.

Progress plans cover up to seven sectors in which specific targets are identified: industry, local electricity production, local heat cold production, municipal buildings equipment facilities, public lighting, residential buildings, tertiary buildings, transport; an eighth sector, called others, includes the remaining local fonts of energy consumption.

Despite the first signatures in 2008, we see in Fig. 1(b) that the first progress plans have been published in 2014, with a delay of six years. In the decade 2008-2017 a total of 1657, 105 and 64 progress plans have been published considering respectively targets 2020, adaptation and 2030. If we analyse the ratio between the total progress plan and the total action plans, we find that for 2020 target we have a coverage of $52.7 \%$, while for adaptation and 2030 targets, the coverage rises up respectively to $105.0 \%$ and $116.4 \%$. Adaptation and 2030 target from this analysis appear to be much better monitored respect to 2020 action plans. Causes of these different coverages need to be deeper analysed since implementation progresses play a fundamental role on the global achievement of GHG reduction [58].

CoM is presently the world's largest initiative that considers actions on energy saving and on local climate. CoM started in Europe in 2008, including in October 2010 already more than 2000 signatories. 


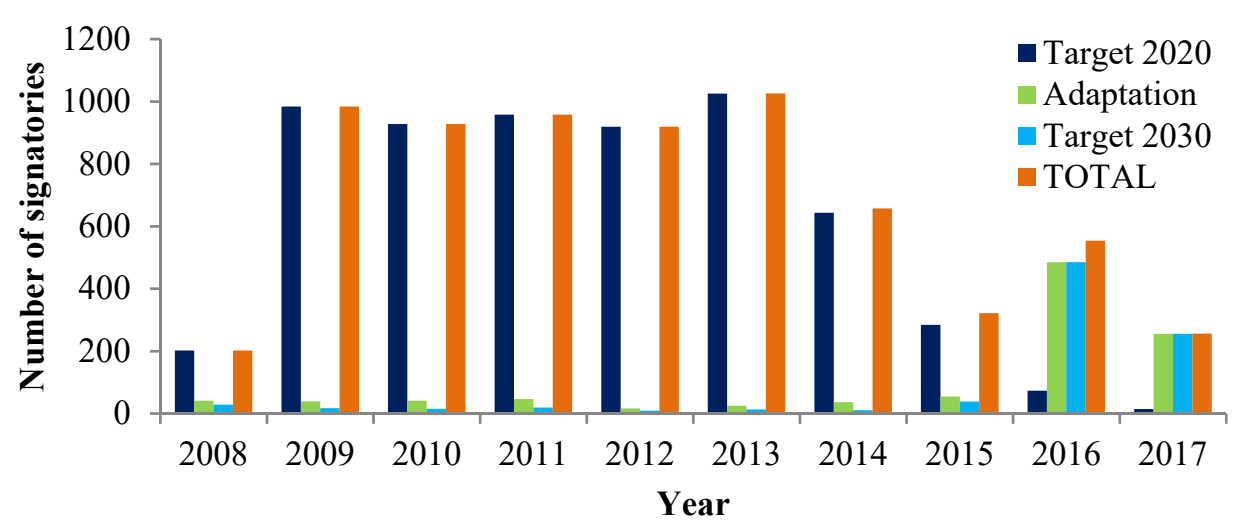

(a)

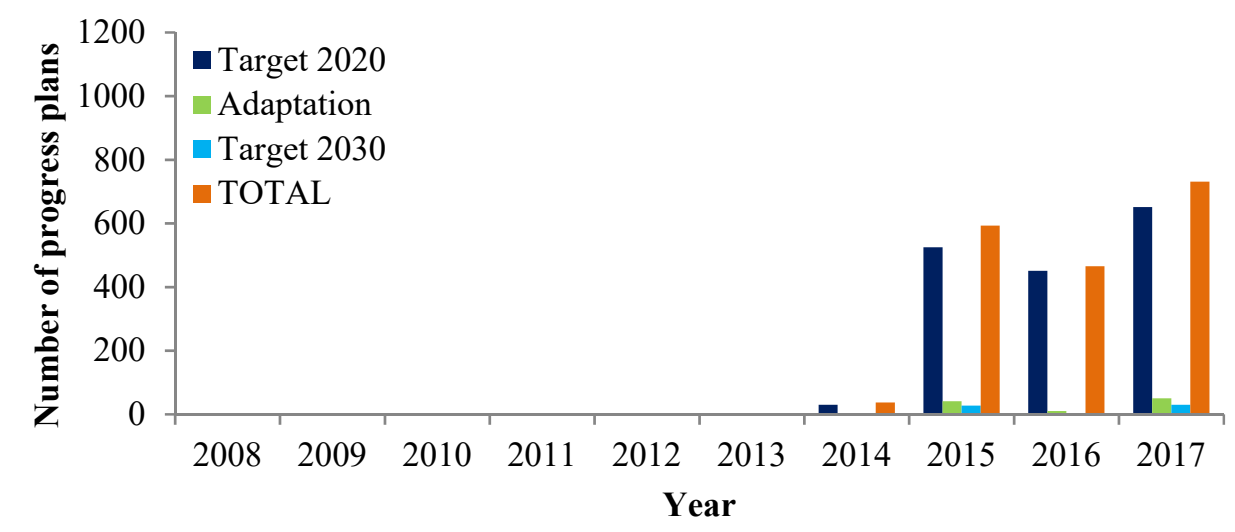

(b)

Figure 1: (a) Signatories of SEAP-SECAP in the period 2008-2017; (b) Progress plans in the period 2008-2017. Colours of the histogram represent the target of the SAEP-SECAP: 2020 (dark blue), adaptation (green), 2030 (light blue). Total number of signatories per year is represented by orange histogram.

The European Commission (EC) decided to broader the initiative in the EU Eastern Parnership countries (2011), to the European Neighbourhood South Region (2012) and SubSaharan Africa, America, Japan, India, China and South-East Asia (2015). Mayors Adapt initiative and Compact of Mayors initiative joined together with CoM respectively in 2015 and 2016, resulting in the present Global Covenant of Mayors for Climate and Energy.

In Fig. 2 we present the list of 53 countries with at least one local signatory of SEAPSECAP in the period 2008-2017 and their relative population involved in the CoM initiative. Fig. 2 shows with different colours the European member states (EU28, in blue) and the nonEU28 states (in red). For the period 2008-2017, EU28 countries sum up 79.7\% of the whole population involved in the initiative. The upper $10 \%$ percentile, that covers 5 countries of the list, includes Italy, Spain, United Kingdom, Germany and France. All these countries are in the EU28 and the sum of the population of their signatories covers $53.7 \%$ of the whole 
signatories. The non-EU28 countries with the larger population involved in the initiative are Ukraine and Turkey, both with more than 10 million inhabitants.

Italy is presently the nation with the largest population involved in the initiative, representing by itself $17.3 \%$ of the total. In the next paragraph we describe the Italian experience and its status of implementation.

\section{COVENANT OF MAYORS IN ITALY}

In the period 2008-2017 the number of signatories (single authority and group of authorities) of the CoM initiative in Italy is 3172 . Considering the single local authority covered by SEAPs in Italy, we have 3518 signatories with 2020 targets (43.99\% of the total), 252 signatories with 2030 targets $(3.15 \%)$ and 314 signatories with adaptation target $(3.93 \%)$, on a total of 7998 local authorities in the country. Total population covered by CoM initiative is 41.8 million citizens (68.91\%). We can distinguish 4 phases: (i) 2008-2010 in which almost no signatories are present, (ii) 2011 represents the rising part of the distribution (iii) 20122015 with high number of signatories (75\% of the total) and (iv) 2016-2017 in which a decreasing trend is present. 2 peaks of signatures are present in 2013 and 2015, with more than 700 signatories per year.

Distribution of specific targets identified in the SEAPs in Italy in the period 2008-2017 is shown in Fig. 3. We can distinguish three main classes of targets in term of term of their presence in SEAPs: (A) high-presence targets are represented by municipal buildings equipment facilities, local electricity production and public lighting, (B) intermediatepresence targets include transport, residential buildings and others and (C) low-presence targets include local heat-cold production, tertiary buildings equipment facilities and industry.

Class A includes the two main sources of public energy consumption of a local authority: municipal buildings and public lighting. Local electricity production is in class A, while local heat-cold production is in class C (respectively representing $20.84 \%$ and $3.46 \%$ of the total).

Private buildings (residential, industry and tertiary) sum $13 \%$ of the total even if these sources, together with the source due to transport, commonly represent the majority of GHG emission of local government areas.

In terms of the year selected to reach the target of the SEAP signed, almost all the signatories opted for 2020 (3143, 98.71\% of the total), while only 28 signatories in the period 2008-2017 planned targets with 2030 target year. 2020 targets are present in the signatures in the period 2010-2017, while 2030 targets appear only starting from 2016.

GHG reduction percentage is freely set by the signatories. Reference year for the reduction target is 1990. As already pointed out (e.g. in [22]), up to now rarely 1990 was chosen as reference year mainly due to difficulty for the local administration to evaluate data referred to the year 1990. More likely, year of the Baseline Emission Inventory (BEI) is between 2008 and 2010, e.g. in the Portuguese case [22], resulting in some cases in a more ambitious process to reach the selected target, even if this cannot be always the case [60], [61]. Majority of Italian local administration opted for GHG reduction target in the range $20 \%-30 \%$ (79.53\% of the total), while $12.54 \%$ and $4.40 \%$ respectively fixed the GHG emission reduction target in the ranges $30 \%-40 \%$ and $40 \%-50 \% .103$ signatories $(2.98 \%$ of the total) fixed reduction targets over $50 \%$, in some cases also assuming to become completely carbonneutral by 2050 .

Majority of signatories and population (respectively $97.44 \%$ and $60.32 \%$ of the total) involved in the CoM initiative in Italy are part of small or extra small administrations (population respectively below 50000 or 10000 inhabitants). Different distributions in term of population covered by CoM initiative are present. 


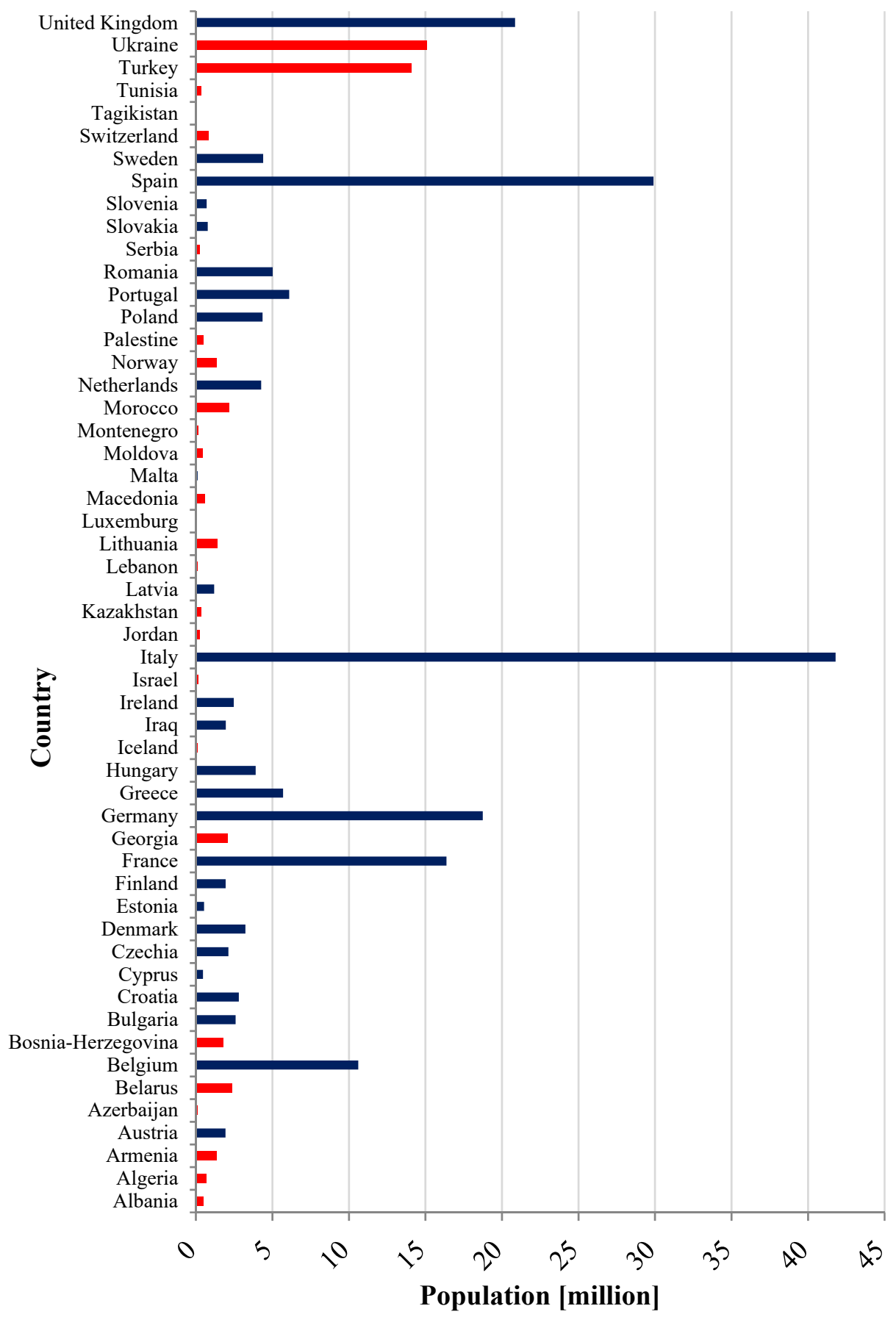

Figure 2: Population per Country covered by Action Plans. Colours of the histogram represent the EU28 countries (blue) and extra EU28 countries (red) respectively. 


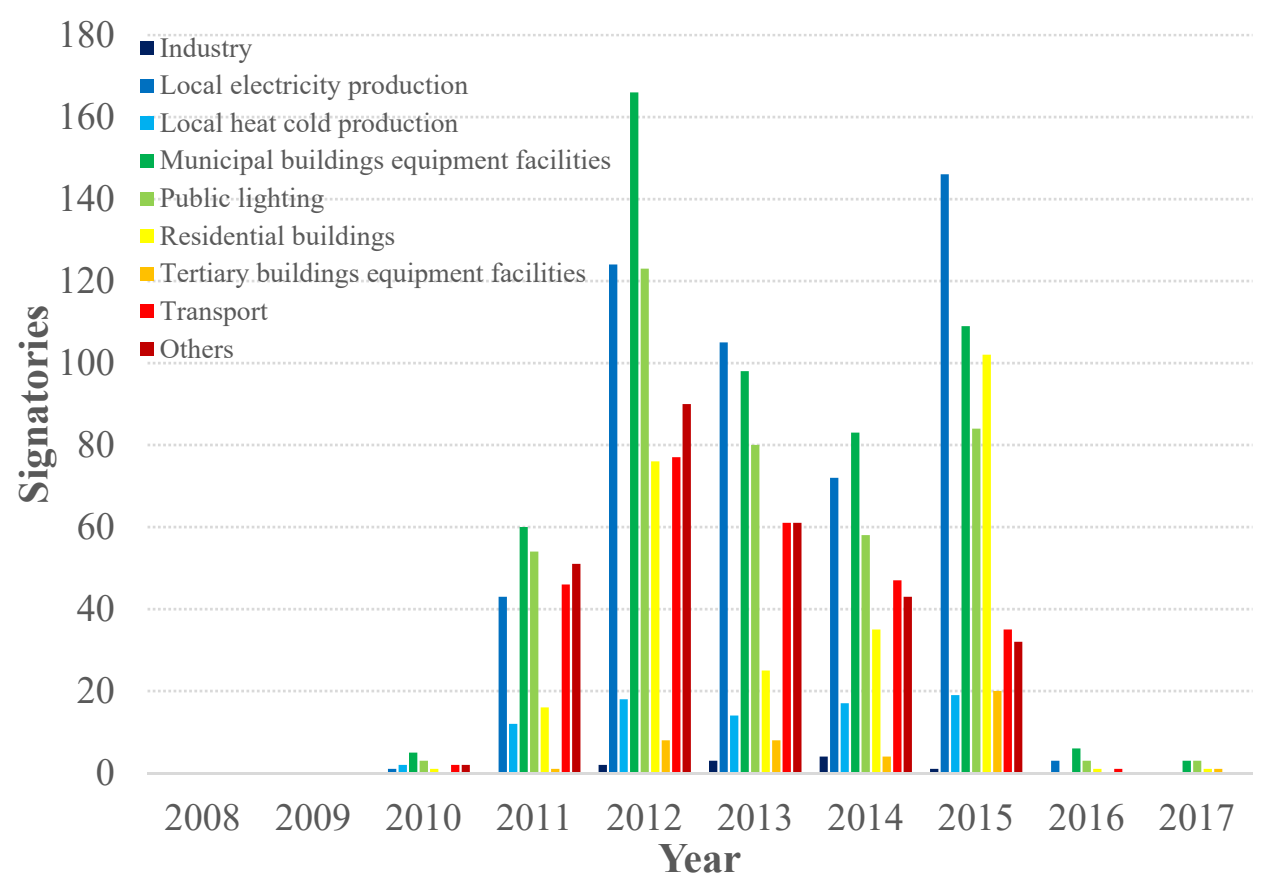

Figure 3: Sectors for which a specific action is assumed in SEAPs in Italy, in the period 2008-2017.

In Fig. 2 we show the territorial coverage assigned to each municipality in Italy participating to CoM distinguished per target: (a) 2020 target, (b) adaptation and (c) 2030 target.

2020 targets cover $141190 \mathrm{~km}^{2}$ (46.7\% of the total Italian territory), while adaptation and 2030 target cover respectively $10119 \mathrm{~km}^{2}$ and $13774 \mathrm{~km}^{2}(3.4 \%$ and $4.6 \%)$.

We consider for the macro-analyses 5 Italian administrative units (AU) as defined by EU first level Classification of Territorial Units for Statistics: North West (Aosta Valley, Liguria, Lombardy, Piedmont), North East (Emilia-Romagna, Friuli-Venezia Giulia, Trentino-Alto Adige/Südtirol, Veneto), Centre (Lazio, Marche, Tuscany, Umbria), South (Abruzzo, Apulia, Basilicata, Calabria, Campania, Molise), Islands (Sardinia, Sicily). In three AU (North West, North East and Islands) the coverage of 2020 mitigation target is over $60 \%$ (respectively $62.84 \%, 66.07 \%$ and $66.95 \%$ ), while Centre and Islands population coverage is lower (respectively $30.46 \%$ and $47.51 \%$ ). The two regions with the lowest coverage, Lazio and Umbria, are part of the Centre AU, with a coverage respectively of $23.76 \%$ and $23.16 \%$, while the two regions with the highest coverage, Abruzzo and Emilia-Romagna (respectively with $79.56 \%$ and $72.49 \%$ ), are part of the South and North East AU.

\section{CONCLUSIONS}

In this paper we presented a review of the first 10 years of the Covenant of Mayors initiative in terms of global parameters like the number of signatories and SEAP-SECAP published, countries and population involved, temporal horizon of the targets, status of implementation 


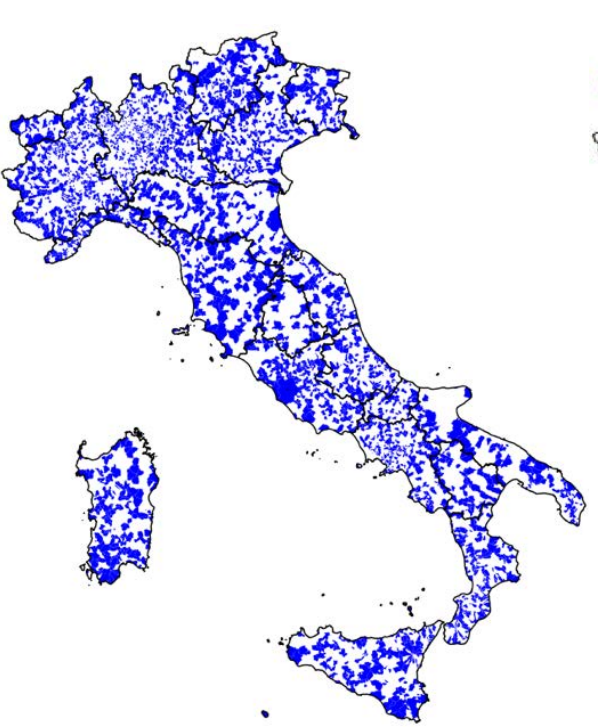

(a)

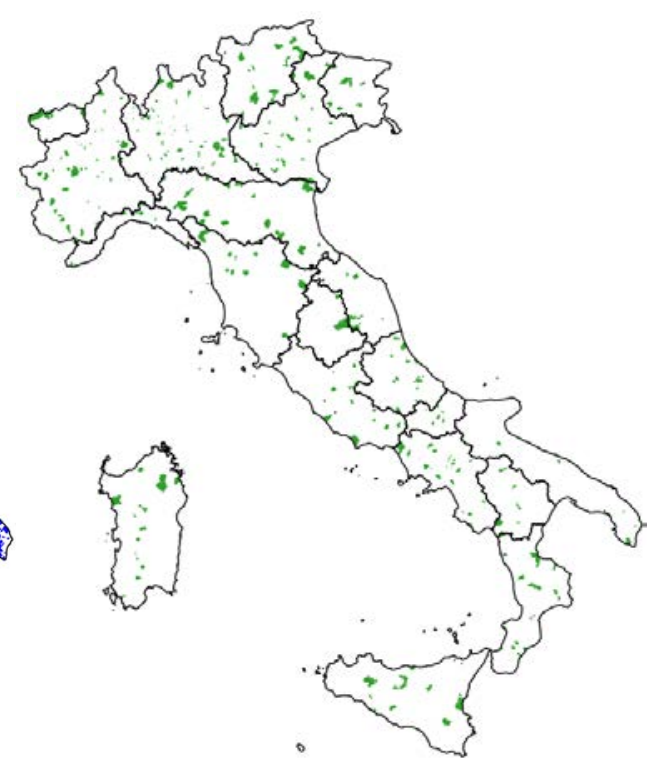

(b)

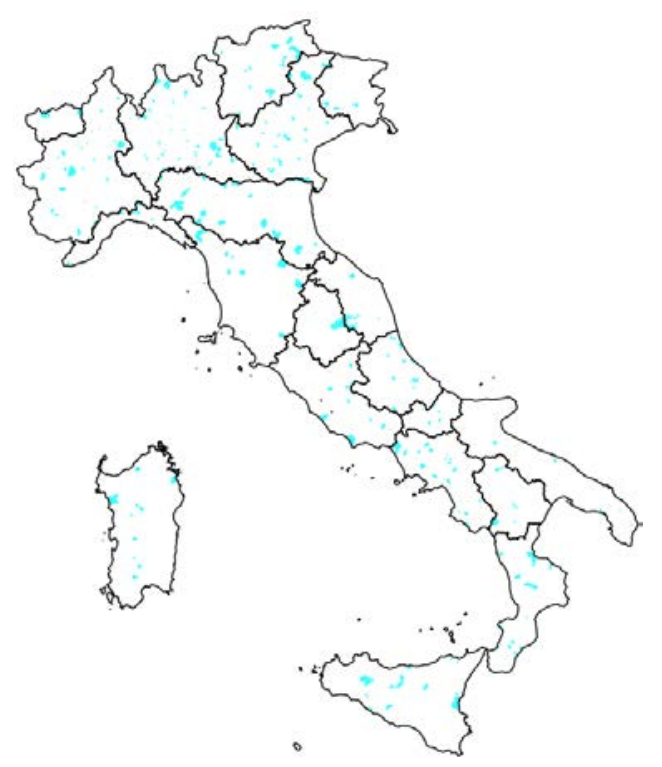

(c)

Figure 4: Status of implementation of the Covenant of Mayors in Italy, showing the administrative areas covered by signatories: Target 2020 (a), in blue; Adaptation (b), in green; Target 2030 (c), in light blue.

of the Progress Plans. Success in terms of signatories and population involved by CoM voluntary initiative in its first decade of activity underlines the increasing awareness at local scale of the global goal of low-carbon economy. Considering EU28, territorial coverage of 
initiative is not homogeneous per country, with a higher density in the Mediterranean area (south of Spain and Italy in particular) and in Belgium.

Furthermore, we showed the status of implementation of the CoM initiative in Italy, that is presently the country with the larger population involved. In terms of specific targets, highpresence of the categories named (i) municipal buildings equipment facilities, (ii) local electricity production and (iii) public lighting emphasises the role of the signatories, that are public local authorities or group of them. Private contribution to the local targets due to e.g. residential buildings, tertiary buildings and industries is less represented in the SEAPSECAP, even if they largely contribute, together with transport, to the total of GHG emissions.

Despite EU encourages climate actions with local emphasis, sometimes a limited presence of technical staff supporting local authorities that is appropriately trained on this specific topic could limit the development of targets and consequently the monitoring phase.

Local sustainable energy production, in the more general view of a local circular economy, can positively contribute to reach the goals fixed by EU and in order to improve the resilience of Earth's climate, but it is necessary to constantly monitor the whole of the actions and also to have an estimate of the emissions (e.g. BEI here described) of local authorities that are actually excluded from the initiative in order to give an overall opinion in terms of percentage of GHG emissions.

\section{ACKNOWLEDGEMENT}

Thanks are due for the financial support to Municipality of Oppeano (Italy).

\section{REFERENCES}

[1] Hurrell, J.W., Decadal trends in the North Atlantic oscillation: Regional temperatures and precipitation. Science, 269(5224), pp. 676-679, 1995.

DOI: 10.1126/science.269.5224.676.

[2] Zachos, J., Pagani, H., Sloan, L., Thomas, E. \& Billups, K., Trends, rhythms, and aberrations in global climate 65 Ma to present. Science, 292(5517), pp. 686-693, 2001. DOI: $10.1126 /$ science. 1059412 .

[3] Walther, G. et al., Ecological responses to recent climate change. Nature, 416(6879), pp. 389-395, 2002.

[4] Parmesan, C. \& Yohe, G., A globally coherent fingerprint of climate change impacts across natural systems. Nature, 421(6918), pp. 37-42, 2003.

DOI: $10.1038 /$ nature 01286 .

[5] Rockström, J. et al., A safe operating space for humanity. Nature, 461(7263), pp. 472475, 2009.

[6] Thomas, C.D. et al., Extinction risk from climate change. Nature, 427(6970), pp. 145148, 2004.

[7] Butchart, S.H.M. et al., Global biodiversity: Indicators of recent declines. Science, 328(5982), pp. 1164-1168, 2010.

[8] Scheffer, M., Carpenter, S., Foley, J.A., Folke, C. \& Walker, B., Catastrophic shifts in ecosystems. Nature, 413(6856), pp. 591-596, 2001. DOI: 10.1038/35098000.

[9] Rogelj, J. et al., Paris Agreement climate proposals need a boost to keep warming well below $2^{\circ}$ C. Nature, 534(7609), pp. 631-639, 2016. DOI: 10.1038/nature18307.

[10] Schleussner, C.-F. et al., Differential climate impacts for policy-relevant limits to global warming: The case of $1.5^{\circ} \mathrm{C}$ and $2^{\circ} \mathrm{C}$. Earth System Dynamics, 7(2), pp. 327351, 2016. DOI: 10.5194/esd-7-327-2016. 
[11] Schleussner, C.-F. et al., Science and policy characteristics of the Paris Agreement temperature goal. Nature Climate Change, 6(9), pp. 827-835, 2016. DOI: 10.1038/nclimate3096.

[12] The EU Strategy on adaptation to climate change; European Union. ec.europa.eu/ clima/sites/clima/files/docs/eu strategy en.pdf. Accessed on: 13 Apr. 2018.

[13] Guidelines on developing adaptation strategies, Commission Staff Working Document; European Union, SWD 134 (2013). ec.europa.eu/clima/sites/ clima/files/adaptation/what/docs/swd_2013_134_en.pdf. Accessed on: 11 Apr. 2018.

[14] Principles and recommendations for integrating climate change adaptation considerations under the 2014-2020 rural development programmes, Commission Staff Working Document; European Union, SWD 139 (2013). ec.europa.eu/clima/ policies/adaptation/what/docs/swd_2013_139_en.pdf. Accessed on: 24 Apr. 2018.

[15] Adapting infrastructure to climate change, Commission Staff Working Document; European Union, SWD 139 (2013). ec.europa.eu/clima/sites/clima/files/ adaptation/what/docs/swd_2013_137_en.pdf. Accessed on: 27 Apr. 2018.

[16] Low-carbon economy. https://ec.europa.eu/clima/policies/strategies/2050_en. Accessed on: 30 Mar. 2018.

[17] Pichler, P.-P., Zwickel, T., Chavez, A., Kretschmer, T., Seddon, J. \& Weisz, H., Reducing urban greenhouse gas footprints. Scientific Reports, 7(1), p. 14659, 2017. DOI: 10.1038/s41598-017-15303-x.

[18] Kona, A. et al., The Covenant of Mayors in Figures and Performance Indicators: 6-Year Assessment. JRC Science and Policy Reports. European Commission, Publications Office of the European Union, 2015.

[19] Lombardi, M., Pazienza, P. \& Rana, R., The EU environmental-energy policy for urban areas: The Covenant of Mayors, the ELENA program and the role of ESCos. Energy Policy, 93, pp. 33-40, 2016. DOI: 10.1016/j.enpol.2016.02.040.

[20] Cosmi C., Salvia M., Di Leo S., Pietrapertosa F. \& Loperte S., Interregional Cooperation as a Key Tool for the Achievement of Strategic-Energy and Climate Targets: The Experience of the INTERREG IVC RENERGY and SEE RE-SEEties Projects. Smart and Sustainable Planning for Cities and Regions. SSPCR 2015. Green Energy and Technology, eds. A. Bisello, D. Vettorato, R. Stephens \& P. Elisei, pp. 335-352, 2017.

[21] Gargiulo, M. et al., An integrated planning framework for the development of sustainable and resilient cities - the case of the InSMART project. Procedia Engineering, 198, pp. 444-453, 2017. DOI: 10.1016/j.proeng.2017.07.099.

[22] Coelho, S., Russo, M., Oliveira, R., Monteiro, A., Lopes, M. \& Borrego, C., Sustainable energy action plans at city level: A Portuguese experience and perception. Journal of Cleaner Production, 176, pp. 1223-1230, 2018. DOI: 10.1016/j.jclepro.2017.11.247.

[23] ICLEI-Local Governments for Sustainability, Local Solutions to Global Challenges, ICLEI Bonn Center, Bonn. http://archive.iclei.org/fileadmin/user_upload/documents/ Global/About_ICLEI/brochures/ICLEI-intro-2009.pdf. 2010.

[24] European Commission, Investing in the Development of Low Carbon Technologies (SET-plan)-Communication from the commission to the European Parliament, the Council, the European Economic and Social Committee and the Committee of the Regions, COM (2014), vol. 15. European Commission: Brussels, 2009.

[25] Batas Bjelic, I. \& Ciric, R.M., Optimal distributed generation planning at a local level-A review of Serbian renewable energy development. Renewable and Sustainable Energy Reviews, 39, pp. 79-86, 2014. DOI: 10.1016/j.rser.2014.07.088. 
[26] Oliver-Solà, J., Armero, M., De Foix, B.M. \& Rieradevall, J., Energy and environmental evaluation of municipal facilities: Case study in the province of Barcelona. Energy Policy, 61, pp. 920-930, 2013. DOI: 10.1016/j.enpol.2013.06.053.

[27] Famoso, F., Lanzafame, R., Monforte, P. \& Scandura, P.F., 2015. Analysis of the covenant of mayors initiative in sicily. Energy Procedia, 81, pp. 482-492, 2015. DOI: 10.1016/j.egypro.2015.12.122.

[28] Mahbub, M.S., Viesi, D. \& Crema, L., Designing optimized energy scenarios for an Italian Alpine valley: the case of Giudicarie Esteriori. Energy, 116, pp. 236-249, 2016. DOI: 10.1016/j.energy.2016.09.090.

[29] Matak, N., Krajačić, G. \& Pilato, A.M., Integrating sustainable energy action plans for island municipalities: Case study of Korcula. Thermal Science, 20(4), pp. 1037-1048, 2016. DOI: $10.2298 /$ tsci151127109m.

[30] Pablo-Romero, M.D.P., Pozo-Barajas, R. \& Sánchez-Braza, A., Analyzing the effects of Energy Action Plans on electricity consumption in Covenant of Mayors signatory municipalities in Andalusia. Energy Policy, 99, pp. 12-26, 2016. DOI: 10.1016/j.enpol.2016.09.049.

[31] Roca, A.V., The promotion of photovoltaic for self-consumption in the local public administration: The case of the Barcelona Provincial Council. Revista de Obras Publicas, 164(3584), pp. 86-91, 2017.

[32] Lombardi, M., Rana, R., Pazienza, P. \& Tricase, C., The European policy for the sustainability of urban areas and the covenant of mayors' initiative: A case study. Pathways to Environmental Sustainability: Methodologies and Experiences, eds. R. Salomone \& G. Saija, Springer-Verlag: Berlin and New York, pp. 183-192, 2014.

[33] Schenone, C., Delponte, I. \& Pittaluga, I., The preparation of the sustainable energy action plan as a city-level tool for sustainability: The case of Genoa. Journal of Renewable and Sustainable Energy, 7(3), p. 033126, 2015. DOI: 10.1063/1.4921723.

[34] Nuss-Girona, S., Llausàs, A., Figueras, J. \& Morera, S., The SEAP in the city of Girona, a crossroads between boldness and pragmatism. Local Environment, 21(4), pp. 476-503, 2016. DOI: 10.1080/13549839.2014.974150.

[35] Scorza, F., Santopietro, L., Giuzio, B., Amato, F., Murgante, B. \& Casas, G.L., Conflicts between environmental protection and energy regeneration of the historic heritage in the case of the city of Matera: Tools for assessing and dimensioning of sustainable energy action plans (SEAP). Lecture Notes in Computer Science, 10409, pp. 527-539, 2017. DOI: 10.1007/978-3-319-62407-5 37.

[36] Amorim, E.V., Sustainable energy action plans: project management intercomparison. Procedia Technologies, 16, pp. 1183-1189, 2014. DOI: 10.1016/j.protcy.2014.10.133.

[37] Croci, E., Lucchitta, B., Janssens-Maenhout, G., Martelli, S. \& Molteni, T., Urban $\mathrm{CO} 2$ mitigation strategies under the Covenant of Mayors: An assessment of 124 European cities. Journal of Cleaner Production, 169, pp. 161-177, 2017. DOI: 10.1016/j.jclepro.2017.05.165.

[38] Haupt W., European municipalities engaging in climate change mitigation and adaptation networks: Examining the case of the covenant of mayors. ResilienceOriented Urban Planning. Lecture Notes in Energy, eds. Y. Yamagata \& A. Sharifi, Springer International Publishing: Cham, 65, pp. 93-110, 2018.

[39] Pietrapertosa, F., Khokhlov, V., Salvia, M. \& Cosmi, C., Climate change adaptation policies and plans: A survey in 11 South East European countries. Renewable and Sustainable Energy Reviews, 81, pp. 3041-3050, 2018. DOI: 10.1016/j.rser.2017.06.116. 
[40] Lee, T., Local energy agencies and cities' participation in translocal climate governance. Environmental Policy and Governance, 28(3), pp. 131-140, 2018. DOI: 10.1002/eet.1798.

[41] Melica, G., Bertoldi, P., Kona, A., Iancu, A., Rivas, S. \& Zancanella, P., Multilevel governance of sustainable energy policies: The role of regions and provinces to support the participation of small local authorities in the Covenant of Mayors. Sustainable Cities and Society, 39, pp. 729-739, 2018. DOI: 10.1016/j.scs.2018.01.013.

[42] Pablo-Romero, M.D.P., Pozo-Barajas, R. \& Sánchez-Braza, A., Analyzing the effects of the benchmark local initiatives of Covenant of Mayors signatories. Journal of Cleaner Production, 176, pp. 159-174, 2018. DOI: 10.1016/j.jclepro.2017.12.124.

[43] Bertoldi, P., Kona, A., Rivas, S. \& Dallemand, J.F., Towards a global comprehensive and transparent framework for cities and local governments enabling an effective contribution to the Paris climate agreement. Current Opinion in Environmental Sustainability, 30, pp. 67-74, 2018. DOI: 10.1016/j.cosust.2018.03.009.

[44] Pablo-Romero, M.P., Sánchez-Braza, A. \& Manuel González-Limón, J., Covenant of Mayors: Reasons for Being an Environmentally and Energy Friendly Municipality. Review of Policy Research, 32(5), pp. 576-599, 2015. DOI: 10.1111/ropr.12135.

[45] Martelli, S. et al., Do voters support local commitments for climate change mitigation in Italy? Ecological Economics, 144, pp. 27-35, 2018.

DOI: 10.1016/j.ecolecon.2017.06.035.

[46] Christoforidis, G.C., Chatzisavvas, K.C., Lazarou, S. \& Parisses, C., Covenant of Mayors initiative. Public perception issues and barriers in Greece. Energy Policy, 60, pp. 643-655, 2013. DOI: 10.1016/j.enpol.2013.05.079.

[47] www.interregeurope.eu/bioregio/.

[48] Cellura, M., Cusenza, M.A. \& Longo, S., Energy-related GHG emissions balances: IPCC versus LCA. Science of the Total Environment, 628-629, pp. 1328-1339, 2018. DOI: $10.1016 /$ j.scitotenv.2018.02.145.

[49] Martire, S., Mirabella, N. \& Sala, S., Widening the perspective in greenhouse gas emissions accounting: The way forward for supporting climate and energy policies at municipal level. Journal of Cleaner Production, 176, pp. 842-851, 2018. DOI: 10.1016/j.jclepro.2017.12.055.

[50] Kyriakarakos, G., Patlitzianas, K., Damasiotis, M. \& Papastefanakis, D., A fuzzy cognitive maps decision support system for renewables local planning. Renewable and Sustainable Energy Reviews, 39, pp. 209-222, 2014. DOI: 10.1016/j.rser.2014.07.009.

[51] Cochran, I., Variant 1: Region/city geographical inventories. V. Bellassen, \& N. Stephan, Accounting for carbon: Monitoring, reporting and verifying emissions in the climate economy. Accounting for Carbon: Monitoring, Reporting and Verifying Emissions in the Climate Economy, Cambridge University Press: Cambridge, pp. 72103, 2015.

[52] Marinakis, V., Papadopoulou, A.G., Doukas, H. \& Psarras, J., A web tool for sustainable energy communities. International Journal of Information and Decision Sciences, 7(1), pp. 18-31, 2015. DOI: 10.1504/ijids.2015.068115.

[53] Marinakis, V., Xidonas, P. \& Doukas, H., A modelling framework for the forecasting of energy consumption and $\mathrm{CO} 2$ emissions at local/regional level. International Journal of Global Energy Issues, 39(6), pp. 444-460, 2016. DOI: 10.1504/ijgei.2016.079374.

[54] Zanni, D., Righi, A., Dalla Mora, T., Peron, F. \& Romagnoni, P., The Energy improvement of school buildings: Analysis and proposals for action. Energy Procedia, 82, pp. 526-532, 2015. DOI: 10.1016/j.egypro.2015.11.865. 
[55] Dall'O', G., Galante, A. \& Pasetti, G., A methodology for evaluating the potential energy savings of retrofitting residential building stocks. Sustainable Cities and Society, 4(1), pp. 12-21, 2012. DOI: 10.1016/j.scs.2012.01.004.

[56] Dall'O', G., Galante, A., Sanna, N. \& Miller, K., On the integration of leadership in energy and environmental design (LEED) ${ }^{\circledR}$ ND protocol with the energy planning and management tools in Italy: Strengths and weaknesses. Energies, 6(11), pp. 5990-6015, 2013. DOI: 10.3390/en6115990.

[57] Berghi, S., Energy use in Urban Transport sector within the Sustainable Energy Action Plans (SEAPs) of three Italian Big Cities. Energy Procedia, 126, pp. 414-420, 2017. DOI: 10.1016/j.egypro.2017.08.193.

[58] Cipriano, X., Gamboa, G., Danov, S., Mor, G. \& Cipriano, J., Developing indicators to improve energy action plans in municipalities: An accounting framework based on the fund-flow model. Sustainable Cities and Society, 32, pp. 263-276, 2017. DOI: 10.1016/j.scs.2017.03.004.

[59] Hsu, A., Cheng, Y., Weinfurter, A., Xu, K. \& Yick, C., Track climate pledges of cities and companies. Nature, 532(7599), pp. 303-306, 2016. DOI: 10.1038/532303a.

[60] Kona, A. et al., Covenant of Mayors: Greenhouse Gas Emissions Achievement and Projections, Publications Office of the European Union: Luxembourg, EUR 28155 EN, 2016.

[61] Olivier, J., Janssens.Maenhout, G., Mountean, M. \& Peters, J., Trends in global $\mathrm{CO}_{2}$ emissions: 2015 Report. Background Studies. PBL Netherlands Environmental Assessment Agency; Ispra: European Commission, Joint Reasearch Centre, The Hague, 2015. 